\title{
Effects of a Composite Endomycorrhizal Inoculum on Olive Cuttings under the Greenhouse Conditions
}

\author{
Fairouz Semane ${ }^{1}$, Mohamed Chliyeh ${ }^{1}$, Zouheir Talbi ${ }^{1}$, Jihane Touati ${ }^{1}$, Karima \\ Selmaoui ${ }^{1}$, Amina Ouazzani Touhami ${ }^{1}$, Abdelkarim Filali-Maltouf ${ }^{2}$, Cherkaoui El $^{1}$ \\ Modafar $^{3}$, Abdelmajid Moukhli ${ }^{4}$, Rachid Benkirane ${ }^{1}$ et Allal Douira ${ }^{1}$
}
${ }^{1}$ Laboratoire de Botanique et de Protection des Plantes, UFR de Mycologie, Département de Biologie, Faculté des Sciences BP, 133, Université Ibn Tofail, Kenitra, Morocco.
${ }^{2}$ Laboratoire de Microbiologie et Biologie Moléculaire, Faculté des Sciences, Université Mohammed V, Agdal, Av. Ibn Batouta, BP 1014, Rabat, Morocco.
${ }^{3}$ Laboratoire de Biotechnologie, Valorisation et Protection des Agroressources, Faculté des Sciences et Techniques, Guéliz, B.P. 618, 40 000, Université Cadi Ayyad, Marrakech, Morocco.
${ }^{4}$ UR, Amélioration génétique des plantes, Institut national de la Recherche agronomique F- 40000 Marrakech, Morocco.

\begin{abstract}
This study was carried out in a nursery to evaluate the impact of mycorrhizal fungi on the cutting's root growth, and root colonization of a Moroccan olive variety 'Picholine Marocaine' under greenhouse conditions during 2 years of cultivation. The results revealed that the inoculation with a composite inoculum of arbuscular mycorrhizal fungi (AMF) stimulated an early root formation and high development of vegetative shoots in inoculated cuttings respectively, 35 days (50 days in the control plots) and 40 days (60 days in the control plots) after their culture. The progressive establishment of mycorrhizal symbiosis in the roots of the inoculated plants showed that the root and vegetative masses were respectively $24 \mathrm{~g}$ and $19.5 \mathrm{~g}$ two years after inoculation. The average height and the leave's number of the inoculated plants relative to the control were respectivelys $42 / 12 \mathrm{~cm}$ and $145 / 12$.
\end{abstract}

The newly formed roots were mycorrhizal and present different structures characteristic of AMF: arbuscules, vesicles, hyphae and spores, whose frequency and intensity reached $90 \%$ and $75 \%$ two years after cuttings cultivation. The arbuscular and vesicular contents and the number of spores were $67 \%, 96 \%$ and 212 spores/ $100 \mathrm{~g}$ of soil respectively. The fourteen species of mycorrhizal fungi isolated from the rhizosphere belong to 4 genera (Glomus, Acaulospora, Gigaspora, and Scutellospora) and three families (Glomaceae, Acaulosporaceae and Gigasporacea). The Glomus genus was the most dominant (65\%) followed by the Gigaspora genus (22\%). Glomus intraradices, Gigaspora sp.2, Glomus versiformes are the most abundant species, their frequency of occurrence are respectively $30 \%, 21 \%$ and $16 \%$.

Keywords-Composite edomycorrhizal inoculum, olive cutting, greenhouse conditions

\section{INTRODUCTION}

In recent years the Moroccan olive sector has enjoyed a period of expansion, both in terms of production and in new land brought under cultivation, a phenomenon that has been accompanied by great activity in olive nurseries. These latter generate plantlets through vegetative propagation techniques widely adopted since it helps produce healthier, better rooted plantlets (Caballero and Del Río, 1994; Porras et al., 1999). For instance, the propagation by rooting of cuttings represents an effective method of vegetative propagation of olive tree (Jaenicke and Beniest, 2003). Some nurseries use micropropagation which provides very fast plants with a lower cost of production (Benderradji et al., 2007; YakoubBougdal et al., 2007). Otherwise, It has been shown that mycorrhizal fungi reduce the stress suffered by olive plantlets at transplant, and that they increase their resistance to disease, improve their water relations and nutrient uptake, increase their rate of photosynthesis, and generally improve their vigor - aspects of great importance in plant propagation systems (Davies et al., 2000). In addition, these fungi can change the morphology of the root system, favoring the establishment of young plants (Citernesi et al., 1998). Numerous papers have reported that plants depend on mycorrhizae for their development in low fertility soils and that the ability of plants to absorb nutrients from these 
substrates affects their growth rate (Jaizme-Vega and Rodríguez Romero, 1997; Porras et al., 2003). Furthermore, differences concerning root morphology and nutrient uptake as well as use efficiency, could be possibly ascribed to the differential AMF colonization by some species (Chatzistathis et al., 2013). Indeed, there is a widespread interest in harnessing the benefits of arbuscular mycorrhizal fungi to increase propagation success, stimulate early root and shoot development as well as protection from diseases that may exist in nurseries (Gianinazzi et al., 2010 ; Khabou et al., 2010 ). These rhizosphere symbionts have received a considerable attention as a potential low-input solution to increase the utilization efficiency of scarce non-renewable fertilizers and increasing nutrient uptake efficiency of crop hosts. However, there are a few studies that report the response of woody cuttings to mycorhization at timing of inoculation during vegetative propagation phase.

The aim of this work was to determine the influence of composite endomycorrhizal inoculum in the development of roots and vegetative buds of olive cuttings in function of time, as well as sporulation of infectious endomycorrhizal species in the rhizosphere of these newly formed roots.

\section{MATERIALS AND METHODS}

The inoculum consists of the endomycorrhizal species mixture belonging to the genera Glomus, Acaulospora and Entrophospora, originating from the rhizosphere of olive trees growing in different regions of Morocco (Kachkouch et al., 2012).

Barley plants were used as a host for the multiplication of mycorrhizal inoculum. Barley seeds were disinfected with Sodium hypochlorite $(5 \%)$ for two minutes; they were rinsed with tap water and sown in pots containing mycorrhizal soil and mycorrhizal roots fragments of the olive trees. These pots were brought to the greenhouse and watered regularly with distilled water and received $100 \mathrm{~mL}$ of a nutritive solution every two weeks. After four weeks of barley cultivation, the roots were recovered and cut into fragments of 1 to $2 \mathrm{~cm}$ length.

The olive cuttings are pieces of woody stems, more or less variable in size, taken from trees of 25 years old. 3 grams of mycorrhizal barley root fragments were used as inoculum, applied to the base of each olive cuttings transplanted into a plastic pots containing disinfected soil. Control cuttings are transplanted into soil that does not contain mycorrhizal roots. The pots containing the inoculated and control olive cuttings were subsequently brought in the greenhouse and watered every two to four days with tap water.

\section{Aerial and vegetative part measurements}

Cuttings were harvested 60 days after the experiment start. At each time, the condition of cutting was rated as rooted, callused, or dead. The number of primary and secondary lateral roots on each cutting was counted and removed from the cutting. Fresh weights were obtained from stem and root portions of each cutting using a digital scale. The number of leaves and branches were counted on the vegetative part.

The mycorrhization was assessed on sections of fresh roots of $1 \mathrm{~cm}$ after clearing and staining by modified procedure of Philips and Hayman (1970). The mycorrhizal frequency, arbuscular and vesicular contents inside the root bark are measured by assigning an index of mycorrhization from 0 to 50 : no, 1: trace, 2: less than $10 \%, 3: 11$ to $50 \%, 4: 51$ to $90 \%, 5$ : more than $91 \%$.

Mycorrhizal frequency (F \%):

$\mathrm{F} \%=100 \times(\mathrm{N}-\mathrm{N} 0) / \mathrm{N}$

With, N: number of observed fragments and N0: number of non-mycorrhizal fragments.

Mycorrhizal intensity (M \%):

$\mathrm{M} \%=(95 \mathrm{n} 5+70 \mathrm{n} 4+30 \mathrm{n} 3+5 \mathrm{n} 2+\mathrm{n} 1) / \mathrm{N}$

With, $\mathrm{n}=$ number of fragments assigned with the index 0 , $1,2,3,4$ or 5 .

Arbuscular content (A \%):

$\mathrm{A} \%=(100 \mathrm{~mA} 3+50 \mathrm{~mA} 2+10 \mathrm{~mA} 1) / 100$

Where MA3, MA2, MA1 are the percentages (\%) respectively assigned to the notes $\mathrm{A} 3, \mathrm{~A} 2, \mathrm{~A} 1$, with, $\mathrm{MA} 3=(95 \mathrm{n} 5 \mathrm{~A} 3+70 \mathrm{n} 4 \mathrm{~A} 3+30 \mathrm{n} 3 \mathrm{~A} 3+5 \mathrm{n} 2 \mathrm{~A} 3+\mathrm{n} 1$ A3) / N. The same for A1 and A2.

In this formula, $\mathrm{n} 5 \mathrm{~A} 3$ represents the number of fragments marked with $\mathrm{A} 3$; n4A3 marked the number of fragments 4 with $\mathrm{A} 3 ; \ldots . .$.

A0: no arbuscules, A1: some arbuscules 10\%, A2: moderately abundant arbuscular 50\%, A3: very abundant arbuscular: $100 \%$.

Vesicular content $(\mathrm{V} \%)$ :

$\mathrm{V} \%=(100 \mathrm{mV} 3+50 \mathrm{mV} 2+10 \mathrm{mV} 1) / 100$

Where $\mathrm{mV} 3, \mathrm{mV} 2, \mathrm{mV} 1$ are the percentages $(\%)$ respectively assigned notes $\mathrm{V} 3, \mathrm{~V} 2, \mathrm{~V} 1$, with, $\mathrm{mV} 3=(95$ $\mathrm{n} 5 \mathrm{~V} 3+70 \mathrm{n} 4 \mathrm{~V} 3+30 \mathrm{n} 3 \mathrm{~V} 3+5 \mathrm{n} 2 \mathrm{~V} 3+\mathrm{n} 1 \mathrm{~V} 3) / \mathrm{N}$. The same for $\mathrm{V} 1$ and $\mathrm{V} 2$.

In this formula, $\mathrm{n} 5 \mathrm{~V} 3$ represents the number of fragments marked 5 with V3; n4V3 marked the number of fragments 4 with $\mathrm{V} 3$;

V0: no vesicles; V1: some vesicles 10\% V2: $50 \%$ moderately abundant vesicles; V3 abundant vesicles: $100 \%$.

\section{Spore's extraction}

The wet sieving method described by Gerdemann and Nicolson (1963) was adopted to extract the spores from the rhizosphere of olive cuttings. A quantity of $100 \mathrm{~g}$ of soil was poured into a beaker and then dissolved in 1000 
$\mathrm{mL}$ of tap water. The resulting solution was left to settle for a few seconds and the suspension was decanted into another beaker, stirred and allowed to stand for 10 to 30 seconds. The suspension was then passed through four superimposed sieves with decreasing mesh size (500, 200, 80 and $50 \mu \mathrm{m})$. This operation was repeated twice. The content retained by the sieves of 200,80 and $50 \mu \mathrm{m}$ was divided into two tubes and centrifuged for $4 \mathrm{~min}$ at 9000 rev / min. The supernatant was discarded and a viscosity gradient created by adding $20 \mathrm{~mL}$ of sucrose solution at $40 \%$ in each centrifuge tube. The mixture rapidly stirred and the tube was put again in the centrifuge for $1 \mathrm{~min}$ at $9000 \mathrm{rpm} / \mathrm{min}$. Unlike the first centrifuging, the supernatant was poured into the sieve of $50 \mu \mathrm{m}$, the resulting substrate was rinsed with distilled water to remove sucrose.

The estimation of the number of spores in the soil was made by counting the spores in one $\mathrm{mL}$ of supernatant and by the extrapolation of the total volume $(100 \mathrm{~mL})$. If no spores were observed, the whole supernatant was reduced to $1 \mathrm{~mL}$ and observed again.

\section{RESULTS AND DISCUSSION}

Inoculated and control olive cuttings developed the first roots in approximately 35 and 60 days respectively after

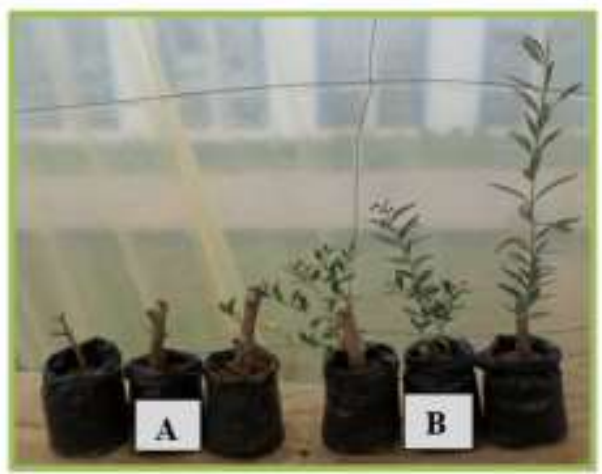

the start of experiment. The first leaves appeared respectively 40 and 60 days in the mycorrhizal and control plants. All inoculated cuttings produce vegetative leaves. On the other hand, only $75 \%$ of the control cuttings were able to develop vegetative branches. In the first year after planting of cuttings, the average number of vegetative leaves in inoculated cuttings was 5 , with an average length of $30 \mathrm{~cm}$ and a number of leaves of 61.7 . While, in the non-inoculated cuttings, the mean number of vegetative branches is 2 per cutting with an average height of $3 \mathrm{~cm}$ and a number of leaves was 8 (Fig. 1, 2, 3 and 4). In the second year, the average number of vegetative leaves in mycorrhizal cuttings decreased to 10.6 with a length of $42 \mathrm{~cm}$ and a number of leaves of 145. The control cuttings had an average of 2 leaves, a length of $12 \mathrm{~cm}$ and 12 as the number of leaves (Fig. 2, 3, 4, and 5).

The mean vegetative biomass was in the order of $19.5 \mathrm{~g}$ after two years in inoculated cuttings compared to $0,9 \mathrm{~g}$ in controls. The development of vegetative biomass is correlated with increasing of the root system. Indeed, rooting was greater on cuttings inoculated with endomycorrhizal inoculum than in non inoculated plants with a large root mass on average of $24 \mathrm{~g}$ per cutting (Figure 6).

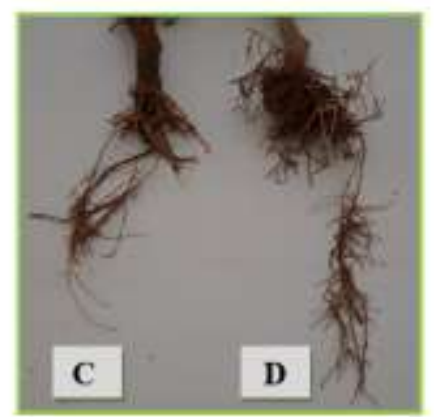

Fig. 1 : Aerial part of control (A);inoculated olive cuttings one year after inoculation (B); Root part of control (C); Inoculated (D) olive cuttings 1 year after inoculation.

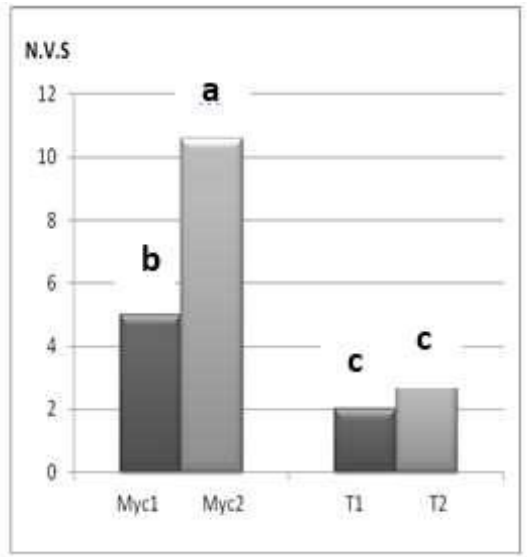

Fig.2: Average number of vegatative buds in olive mycorrhizal cuttings 1year (Myc 1) and 2years (Myc 2) after cultivation and in control cuttings after 1 (T1) and 2 years (T2). 


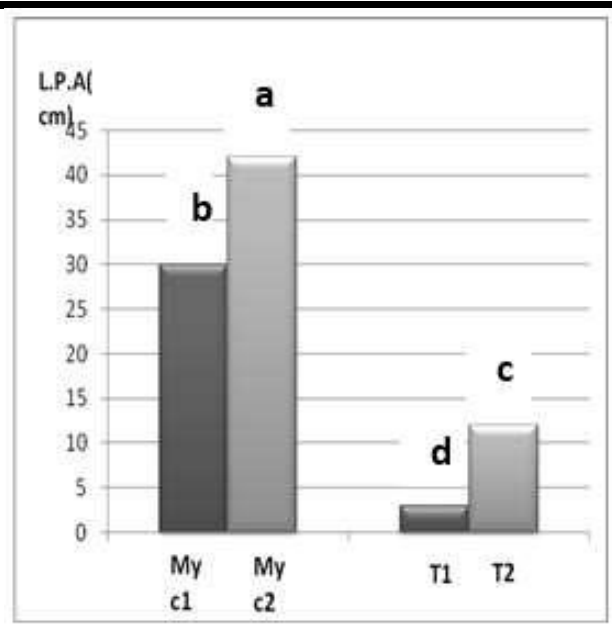

Fig.3: Average length of vegetative buds in olive mycorrhizal cuttings after 1year (Myc 1) and 2years (Myc 2) after cultivation and in control cuttings after 1 (T1) and 2 years (T2).

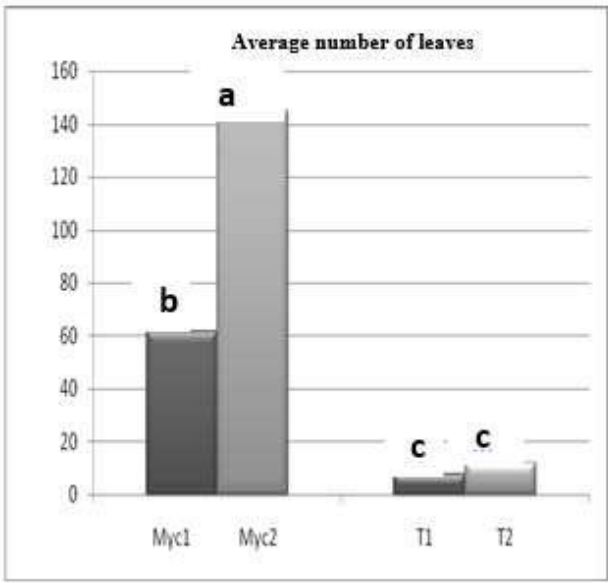

Fig. 4: Average number of leaves of mycorrhizal olive cutting after lyear (Myc 1) and 2 years (Myc 2) after cultivation and in control cuttings after 1 (T1) and 2 years (T2).
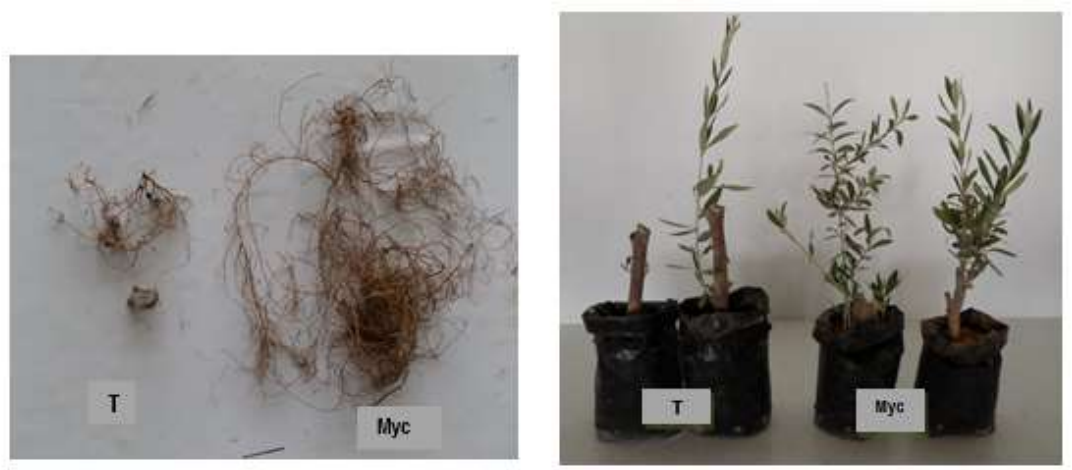

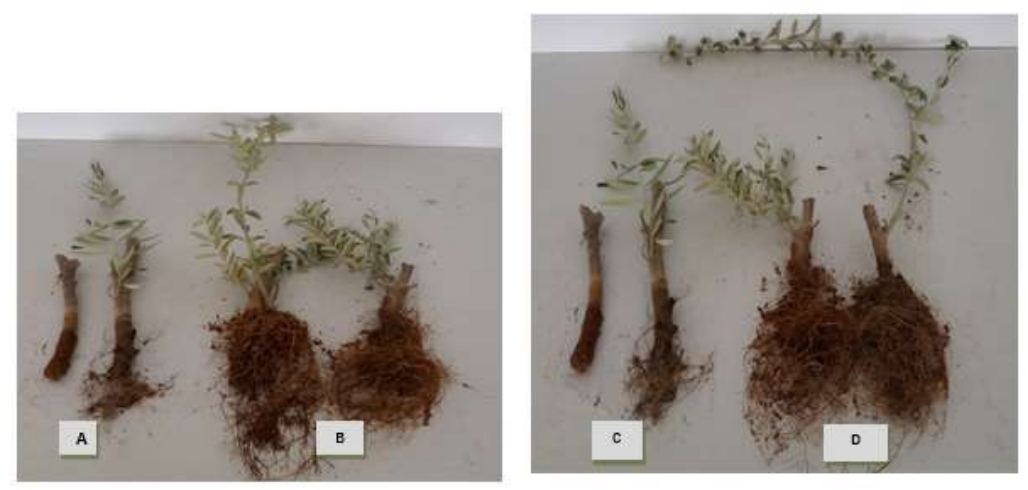

Fig. 5: Aerial and root parts of the of the control cutting 1 year after cultivation (A), (B); Arial and root parts of the inoculated Picholine olive cutting 1 year after cultivation; $(C)$ Aerial and root parts of the control Picholine olive cutting 2 years after cultivation; (D) Aerial and root parts of the inoculated Picholine olive cutting 2 years after cultivation.

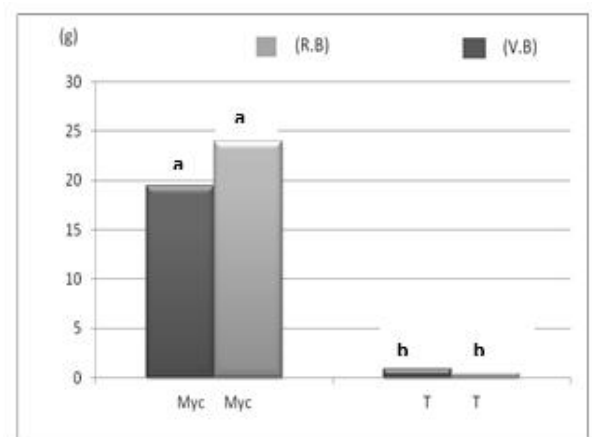

Fig. 6: Vegetative fresh biomass (V.B.) and root fresh biomass (R.B.) in mycorrhizal olive cuttings (Myc) or not (T) 2 years after cultivation. Inoculation.

Table.1: Effect of Mycorrhization on aerial and root growth of olive cuttings.

\begin{tabular}{|c|c|c|}
\hline $\begin{array}{c}\text { Olive } \\
\text { Puttings }\end{array}$ & Mycorhizal cuttings & Control cuttings \\
\hline Leave'snumber & 145 & 12 \\
\hline $\begin{array}{c}\text { Vegetative buds number } \\
\text { part (cm) }\end{array}$ & 10.6 & 12 \\
\hline $\begin{array}{c}\text { Average length of vegetative } \\
\text { Root fresh biomasses (g) }\end{array}$ & 42 & 0.4 \\
\hline $\begin{array}{c}\text { Vegetative fresh biomasse } \\
(\mathrm{m})\end{array}$ & 24 & 0.9 \\
\hline
\end{tabular}




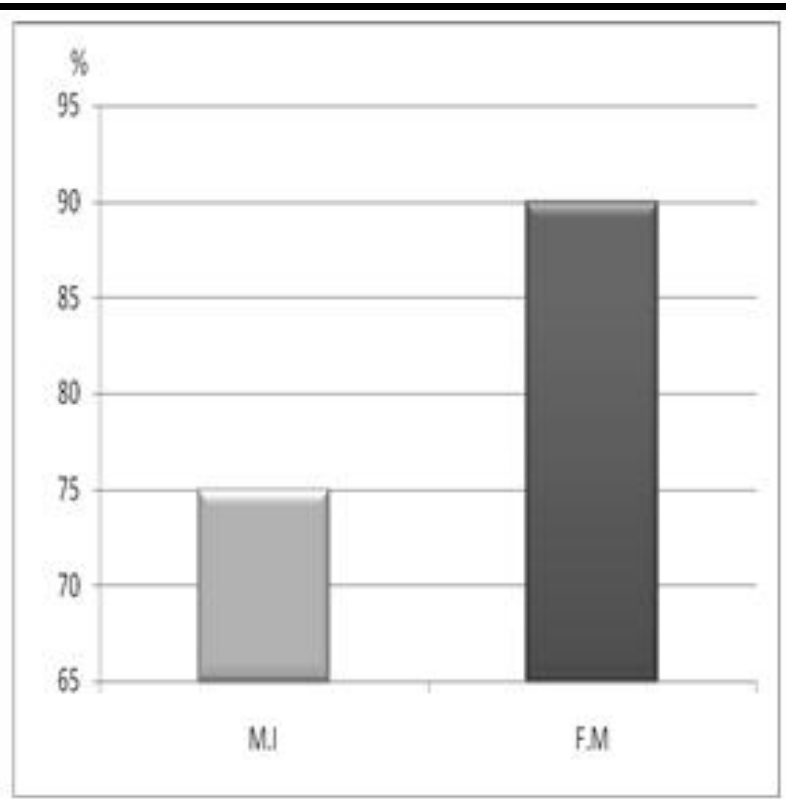

Fig.7: Mycorrizal Intensity (MI) and frequency (FM) in roots of olive cuttings after 2 years of inoculation.

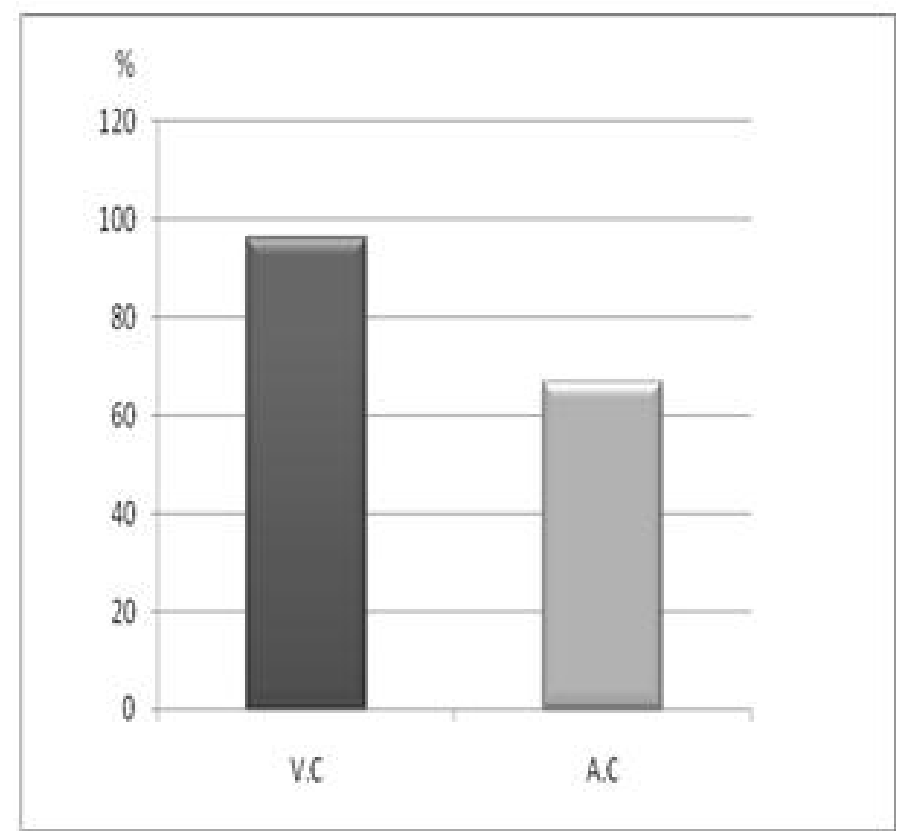

Fig. 8: Vesicular and arbuscular contents in roots of olive cuttings after 2 years of inoculation. 

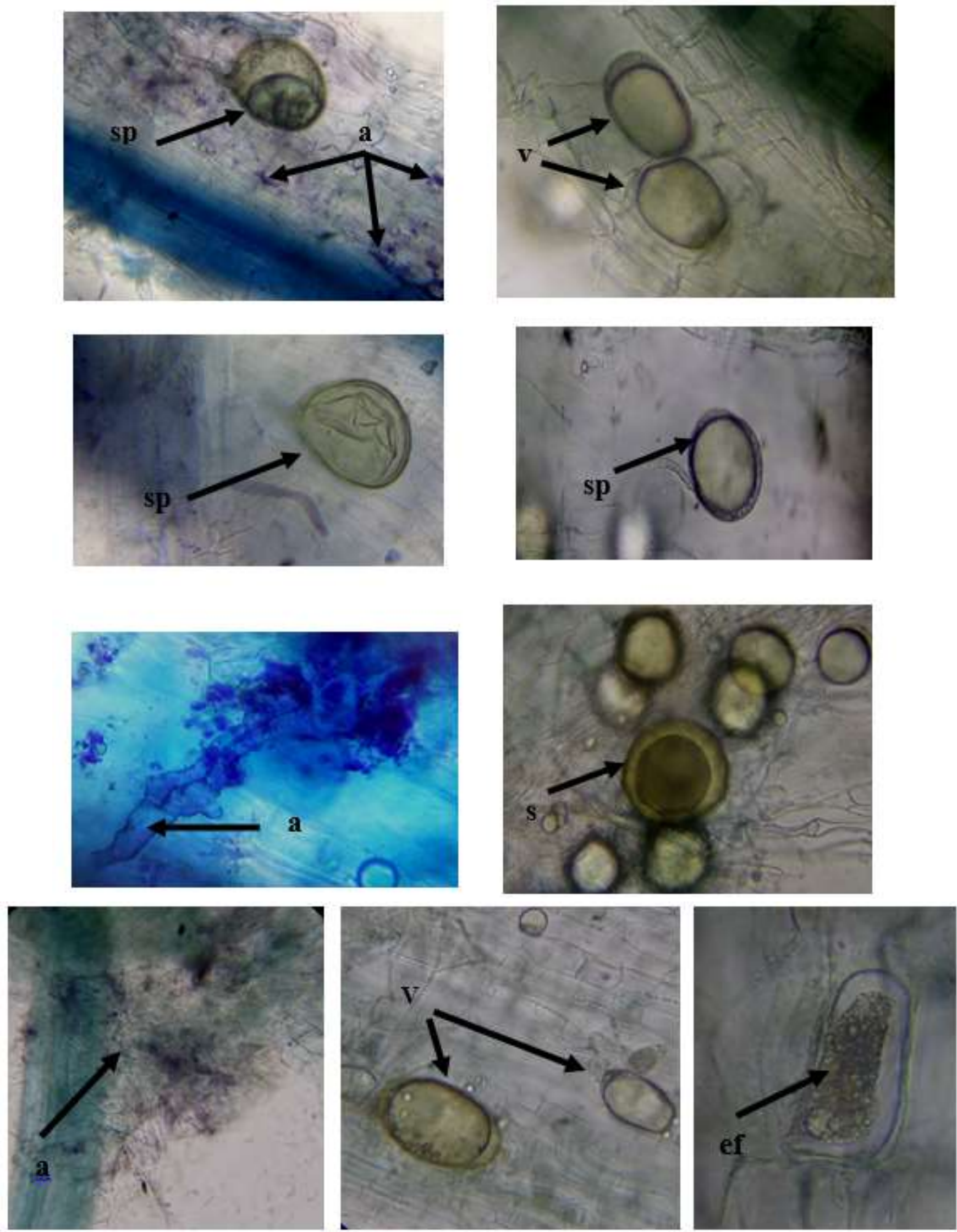

Fig.9: Endomycorrhizal structures formed in the association of mycorrhizae/olive tree cuttings: sp: spores; v: vesicles; ef: endophytes; a: arbuscules. $G \times 400$. 

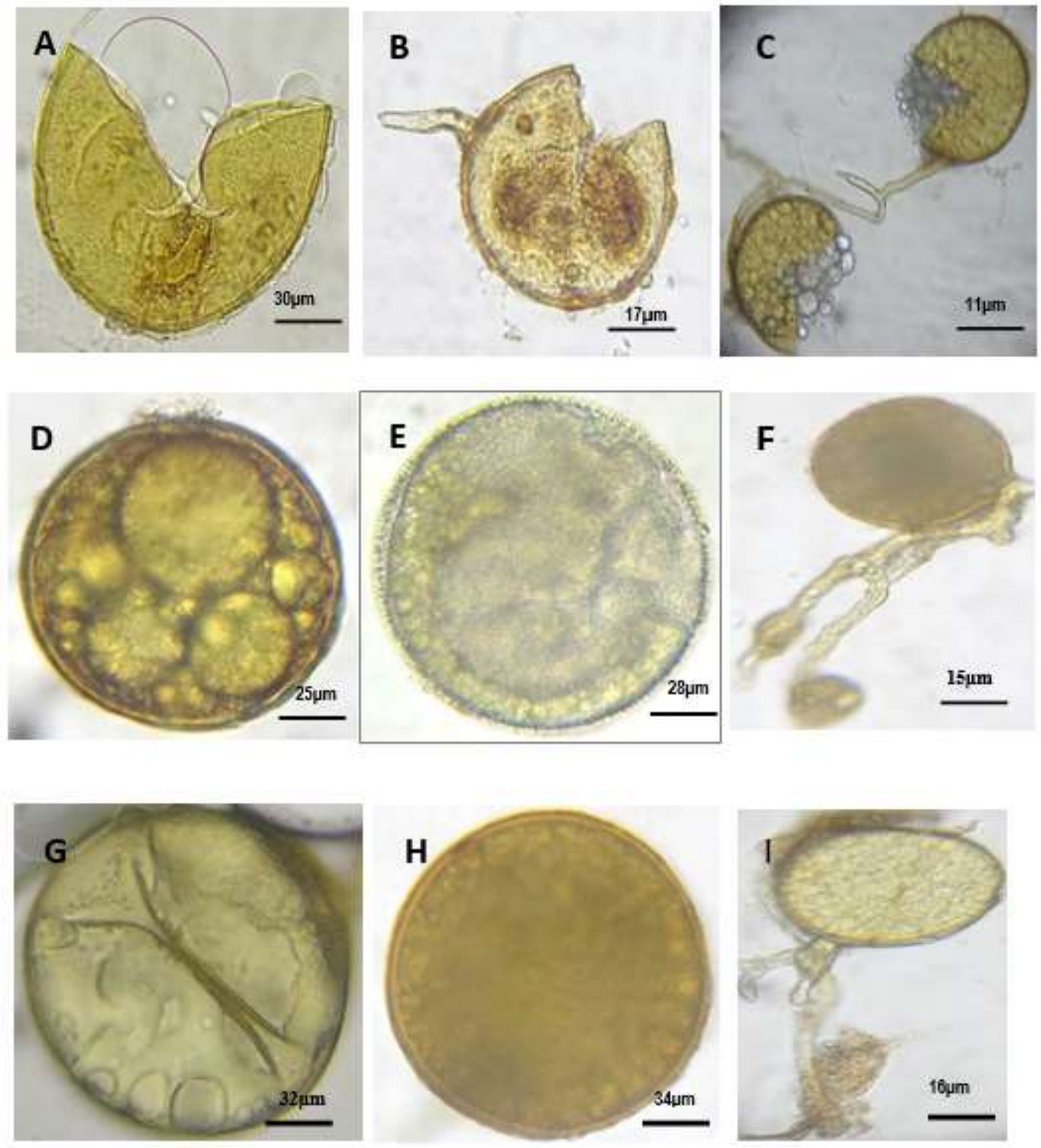

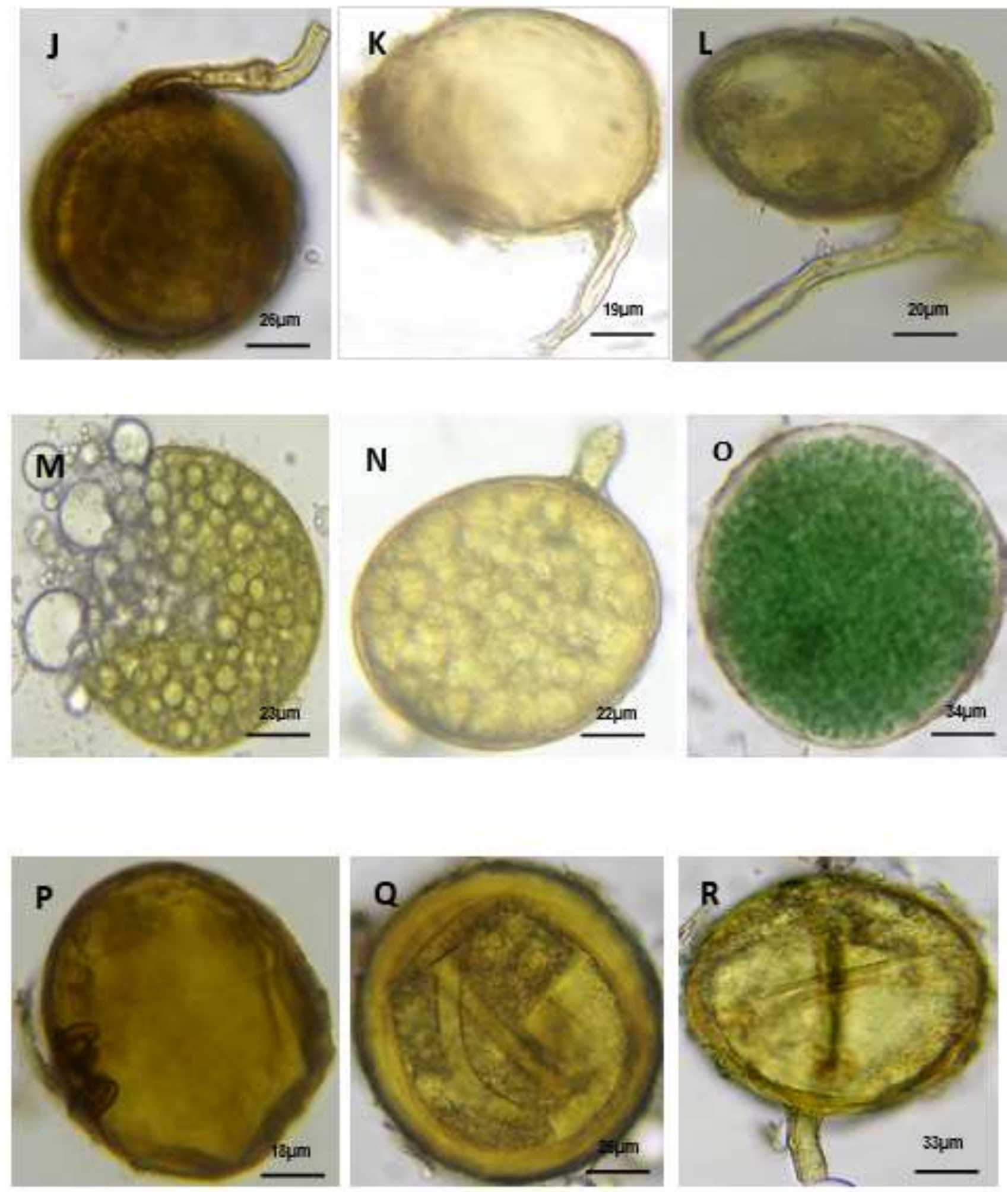

Fig. 10 :Endomycorrhizal spores isolated from the rhizosphere of mycorrhizal olive cuttings (×400). A: Acaulospora scrobiculata; B :Glomus macrocarpum; $(C, L, M, N)$ : Glomus intraradices; D : Glomus versiforme; E: Gigaspora sp.1, F, H: Glomus clarum; G: Scutellospora fulgida; I: Glomus aureum; J: Glomus aurantium; K: Glomus geosporum; $O$ : Gigaspora sp2; P: Scutellospora heterogama; Q: Glomus corymbiforme; R: Glomus microcarpum. 


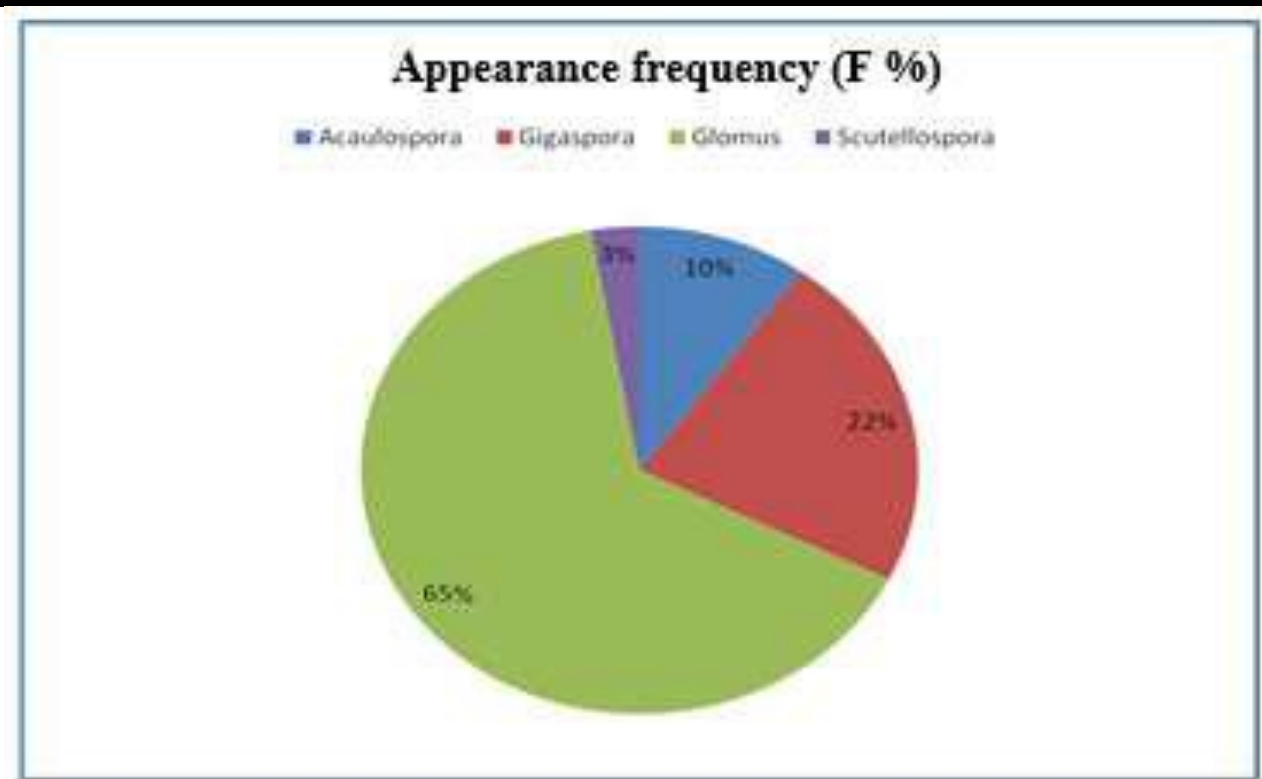

Fig. 11: Appearance frequency of all genera associated with the rhizosphere of olive cuttings inoculated with a composite endomycorrhizal inoculum.

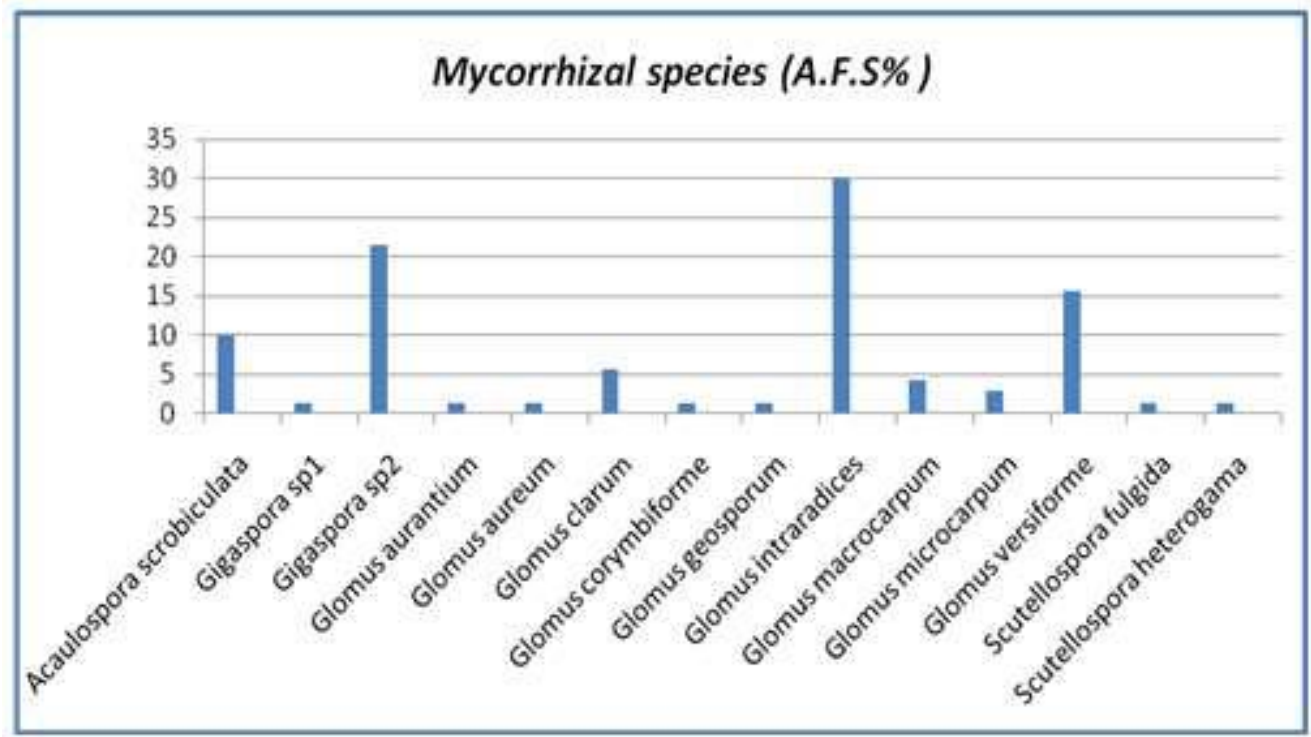

Fig. 12: Isolation frequency of mycorrhizal species in the rhizosphere of olive cuttings inoculated with mycorrhizae after 20 months of culture.

The root system of the mycorrhizal cuttings was more developed, with adventitious and lateral roots of the $1^{\text {st }}$, $2^{\text {nd }}$ and $3^{\text {rd }}$ order (Figure 5). In contrast, control olive cuttings showed a lower development in the root system of $0.4 \mathrm{~g}$ per cutting (Figure 6).

The data in table 1 demonstrated the positive effect of the endomycorrhizal species on different growth parameters of the aerial parts of inoculated olive cuttings that showed greater development than controls.

The evaluation of mycorrhizal root colonization of the olive cuttings showed an important intensity and frequency of mycorrhization reaching respectively $75 \%$ and $90 \%$ (Figure 7).

Also the arbuscular and vesicular content of mycorrhizal cuttings were respectively $67 \%$ and $96 \%$ (Figure 8). Microscopic observation of root fragments showed that the inoculated plants were successfully mycorrhizal. These observations also revealed the presence of endophytes, hyphae, arbuscules and vesicles (Figure 9). The revealed spore's density in the olive's cutting rhizosphere was 212 spores / $100 \mathrm{~g}$ of soil.

The isolation of mycorrhizal fungi from the rhizosphere soil has allowed to note the presence of 14 species of 
endomycorrhizal fungi; Acaulospora scrobiculata, Glomus macrocarpum, Glomus intraradices, Glomus versiforme, Gigaspora sp. 1, Glomus clarum, Scutellospora fulgida, Glomus aureum, Glomus aurantium, Glomus geosporum, Gigaspora sp. 2, Scutellospora heterogama, Glomus corymbiforme, Glomus microcarpum (Figure 10) belonging to 4 genera: Glomus, Acaulospora, Gigaspora and Scutellospora (Fig 11, 12) with a dominance of Glomus which presents $65 \%$ of the isolated species.

Thus, the study of the effects of composite endomycorrhizal inoculum on the rooting of woody cuttings of the olive plants has proved its advantageous impact on growth of roots, aerial parts, shoots and leaves in the early stage of cultivation. The presence of endomycorrhizal fungi with the cuttings probably stimulated their early root production and the progressive development over time, of the young formed roots explains the important effect observed on the growth of the roots and vegetative buds, expressed by the root and aerial fresh weight, the vegetative part length, the number of vegetative branches and the number of leaves.

Some studies have shown that mycorrhizae, by the development of the mycelium, modify the general architecture of the roots (Smith and Read, 1997; Berta et al., 1995). Indeed, the improvement of ramification of root system by mycorrhizal fungi was proved on other hosts, Vitis vinifera (Schellenbaum et al., 1991), Populus sp. (Hooker et al.,1992; Nounsiet al., 2015), Platanus acerifolia (Tisserant et al., 1992), Prunus ceracifera (Fortuna et al., 1998), Coffea arabica (AlAreqi et al.,2014), Olea europaea (Chliyeh et al., 2014) and Ceratonia siliqua (Talbi et al., 2015).

Moreover, using the endomycorrhizal fungi in the rooting substrate increase the success rate of cuttings. The recorded percentage was $100 \%$ which remained stable after 24 months of cultivation, but in control cuttings, it was lower, and varied respectively from $45 \%$ to $75 \%$ after 12 and 24 months after plantation.

Concerning, non rooted control cuttings and those having not enough developed roots, they died during 6 weeks and the first year of cuttings respectively. Such findings remains inexplicable at the moment, but there is a trend to get sure that cuttings mortality can only be related to inoculations with endomycorrhizal fungi. Indeed, the noted root and vegetative biomass for some noninoculated cuttings after their survival and rooting was lower than that observed amongst mycorrhizal cuttings. The presence of endomycorrhizal fungi in the rooting substrate therefore influences the quality of rooting. However, there is conflicting information on the influence of mycorrhizal fungi on rooting of cuttings. Nelson (1987), for example, he noted that colonization of the roots of certain ornamental woody plants species by the mycorrhizal fungi does not mean that the symbiosis is sufficiently functional for the plant to derive all its benefits. It has been noted that sometimes the colonization of the roots is slow, take up 3 or 5 months, and depends on the plant species Nelson (1987). Tréparnier (1998) reported that when propagules of endomycorrhizal fungi are distributed throughout the growing substrate, cuttings take longer time to be colonized, as roots must first pass close to a spore. According to this author, the location of the propagules of fungi in direct contact with the base of the stem as soon to rooting could reduce the duration of infections and thus, the effects on growth would be more perceptible.In the same context, Doudsand al. (1995) obtained significantly increased survival and a better percentage of rooting for Sciadopitys verticillata cuttings in a substrate containing Glomus intraradices propagules. In agreement with our results, vesicular and arbuscular mycorrhizal fungi (VAMF) colonization has shown to increase the survival and growth of rose explants (Wilson et al., 1997) and strawberry transplants (Chavez and Cerrato, 1990). Verkade et al. (1988) found that inoculation of Cornus sericea cuttings with Glomus fasciculatum substantially increased plant growth during later stage of development. In soil substrates lacking indigenous mycorrhizal fungi, mycorrhizal inoculation has been found to increase crop uniformity, reduce transplant mortality and increase productivity of geranium (Biermann and Linderman, 1983), onion (Vosatka, 1995), Cyclamen persicum, Euphorbia pulcherrima (Vosatka et al., 1999). In other experiment, the study of the effect of mycorrhizal fungi on the rooting of miniature rose cuttings demonstrate that the root colonization resulting from inoculation could result in a higher quality cutting that is able to withstand the stress of transplanting and increase growth during later stage of plant development. Indeed, the positive effect on plant growth was attributed to improved absorption of water and nutrients provided by the extended fungal hyphae and the increased root length and density (Bethlenfalvay et al., 1988; Faber et al., 1991; Fouad et al., 2012, 2013; Essahibi et al., 2013).

In conclusion, the used endomycorrhizal inoculum showed a positive effect both on early rooting of woody cuttings and on the formation of vegetative branches. The advantage of mycorrhization increased during the first year and the second year of cultivation giving the improvement of root structure and enhanced fresh root and vegetative part weight of olive cuttings over time. Additionally, our experiments prove the efficiency of endomycorrizal inoculum to support the survival of 
cuttings and its rooting. Moreover, in function of time, the mycorrhization rate increases and became more effective.

\section{ACKNOWLEDGMENTS}

This study was conducted under the project 'Rhizolive: Selection and use of soil rhizospheric microorganisms to optimize the arbuscular mycorrhization of the olive tree in Morocco's soils funded by Hassan II Academy of sciences and technology.

\section{REFERENCES}

[1] Al-Areqi A.H.N.A., Chliyeh M. Ouazzani Touhami A., Benkirane R,. Douira A., 2014. Effect of a composite endomycorrhizal inoculum on the growth of Coffea arabica seedlings. International Journal of Plant, Animal and Environmental Sciences, 4(1): 185-194.

[2] Berta G., Trotta A., Fusconi A., Hooker J.E., Munro M., Atkinson D., Giovannetti M., Morini S., Fortuna P., Tisserant B., Gianinazzi- Pearson V. \& Gianinazzi S., 1995. Arbuscular mycorrhizal induced changes to plant growth and root system morphology in Prunus cerasifera. Tree Physiol. 15: 281-293.

[3] Bethlenfalvay G. J., Brown M. S., Ames R. N., Thomas R.E., 1988. Effects of drought on host and endophyte development in mycorrhizal soybeans in relation to water use and phosphate uptake. Physiol. Plant 72: 565-571.

[4] Biermann B.J., and Linderman R. G. 1983. Increased geranium growth using pretransplant inoculation with a mycorrhizal fungus. J. Amer. Soc. Hort. Sci. 108: 972-976.

[5] Blaszkowski J., Czerniawska B., 2008. Israeli soils are rich in arbuscularmycorrhizal fungi of the phylum Glomeromycota. Proc. Poland-Israel Sci. Irrigation Conf., 213-228.

[6] Brundrett M. C., Abbott L. K., Jasper D. A., 1999. Glomale an mycorrhizal fungi from tropical Australia. I. Comparison of the effectiveness and specificity of different isolation procedures. Mycorrhiza, 8: 305-314.

[7] Caballero J.M., and Del Río C., 1994. Propagación del olivo por enraizamiento de estaquillas semileñoso bajo nebulización. Comunicaciones I + D agroalimentaria, 7-94. Consejería de Agricultura y Pesca, Junta de Andalucía, $23 \mathrm{pp}$.

[8] Chatzistathis T., Orfanoudakis M., Alifragis D., and Therios I. 2013. Colonization of Greek olive cultivars' root system by arbuscular mycorrhiza fungus: root morphology, growth, and mineral nutrition of olive plants. Sci. Agric. 70(3): 185-194.
[9] Chavez M.C.G., and Cerrato R. F. 1990. Effect of vesicular arbuscular mycorrhizae on tissue culture derived plants of strawberry. Hort. Sci. 25: 903-905.

[10] Chliyeh M., Ouazzani Touhami A., Filali-Maltouf A., El Modafar C., Moukhli A, Oukabli A., Benkirane R., Douira A., 2014. Effect of a composite endomycorrhizal inoculum on the growth of olive trees under nurseries conditions in Morocco. International Journal of Pure and Applied Bioscience, 2(2): 1-14.

[11] Chouard P., 1948. Les progrès récents dans la connaissance et l'emploi des substances de croissance. Revue internationale de Botanique appliquée et d'Agriculture tropicale, 311(28) : 427452.

[12] Citernesi A. S., Vitagliano C., Giovannetti M. 1998. Plant growth and root system morphology of Olea europea L. rooted cuttings as influenced byarbuscular mycorrhizas. J Horticult. Sci. Biotechnol. 73: 647-654.

[13] Davies F.T., Estrada-Luna A., Finnerty T.L., Egilla J.N., Olalde-Portugal V., 2000. Applications of mycorrhizal fungi in plant propagation systems. In: Ecología, Fisiología y Biotecnología de la MicorrizaArbuscular (A. Alarcón and R. Ferrera, eds.). IRENAT Colegio de Post graduados. Montecillo. Mundi-Prensa, Madrid, Spain, pp. 123140.

[14] Douds D.D., Galvez L., Janke R.R. and Wagoner P., 1995. Effect of tillage and farming system upon populations and distribution of vesicular arbuscularmycorrhizal fungi. Agriculture Ecosystems and Environment, 52:111-118

[15] Duponnois R., Ramanankierana H., Hafidi M., Baohanta R., Baudoin E., Thioulouse J., Sanguin H., Bâ A., Galiana A., Bally R., Lebrun M., Prin Y., 2013. Des ressources végétales endémiques pour optimiser durablement les opérations de réhabilitation $\mathrm{du}$ couvert forestier en milieu méditerranéen et tropical : exemple des plantes facilitatrices vectrices de propagation des champignons mycorhiziens Comptes rendus biologies, 336(5-6):265-272.

[16] Essahibi A., Cavallaro V., Barbera A., Qaddoury A., 2013. Effect of arbuscularmycorrhizal fungi (AMF) on growth and physiology of carob seedling under nursery conditions. Proc First Int. Am. Morocco. Agr. Sci. Conf., Rabat (Morocco), Mar 18-19. pp: 56-57.

[17] Faber B. A., Zasoske R. J., Munns D. N., Shackel K., 1991. A method for measuring hyphal nutrition and water uptake in mycorrhizal plants. Can. J. Bot. 69: 87-94. 
[18] Fortuna P., Citernesi S., Morini S., Giovannetti, M., 1992. Loreti, F. Infectivity and effectiveness of different species of arbuscular mycorrhizal fungi in micropropagated plants of $\mathrm{Mr} \mathrm{S} 2 / 5$ plum rootstock. Agronomie, 12:825-830.

[19] Fouad M. O., Essahibi A., Qaddoury A., 2012. Effects of arbuscularmycorrhizal fungi on growth, water relation and antioxidant enzymes activities in Moroccan picholine olive plantlets under water stress. Proc Integrated Soil Fertility Management in Africa: from microbes to markets. Nairobi (Kenya), Oct 19-26, pp: 99-100.

[20] Fouad M.O., Essahibi A., Qaddoury A., 2013. Arbuscular mycorrhizal fungi enhanced hardening and post hardening water stress tolerance of under mist system rooted semiherbaceous olive cuttings. Proc 7th Int. Conf. "Mycorrhiza for All: An UnderEarth Revolution", New Delhi (India), Jan 6-1, pp: 216-217.

[21] Gerdemann J.W. \& Nicholson T.H., 1963. Spores for mycorrhizal endogone species extracted from soil by wet sieving and decanting. Trans. Br. Mycol. Soc., 46: 235-244

[22] Gianinazzi S., Golotte A., Binet M.N., van Tuinen D., Redecker D. and Wipf D., 2010. Agroecology: the key role of arbuscular mycorrhizas in ecosystem services. Mycorrhiza, 20: 519-530

[23] Hayman D.S., Barea J.M. and Azcon R., 1976. Vesicular a mycorhiza arbuscular In southern Spain: Its distribution in crops growing in soil of different fertility. Phytopathologia Mediterranea, 15: 1-16.

[24] Hooker J.E., Munro M. and Atkinson D., 1992. Vesicular arbuscular mycorrhizal fungi induced alteration in poplar root system morphology. Plant Soil, 145: 207- 214.

[25] Jaenicke H. et Beniest J., 2003. La multiplication végétative des ligneux en agroforesterie. Manuel de formation et bibliographie. World Agroforestry Centre (ICRAF), Kul Graphics Ltd, Nairobi (Kenya).

[26] Jacquiot C., 1949. Observations sur la néoformation de bourgeons chez le tissu cambial d'Ulmus campestris cultivé in vitro. C. R. Acad. Sci. Paris 229 : 529-530.

[27] Jaizme-Vega M.C., Rodríguez-Romero A.S., 1997. Aplicación de micorrizas sobre el cultivo de platanera. Avances de la investigación en Canarias. Available in: http://www.agroecologia.net/hacemos/micobana.pdf [25 May 2004].

[28] Kachkouch W., Ouazzani Touhami A., FilaliMaltouf A., El Modafar C., Moukhli A.,
Oukabli A., Benkirane R., Douira A., 2012. Arbuscular mycorrhizal fungi species associated with rhizosphere of Olea europaea L. in Morocco. Journal of Animal \& Plant Sciences, 15(3): 22752287

[29] Khabou W., Nacer H. and Fortin A., 2010. La mycorhization : Une méthode biotique pour améliorer la croissance et contourner le stress abiotique chez l'olivier (Olea europaea L.). Revue Ezzaitouna, 11 (2): 1-10.

[30]Le Tacon F., Mousain D., Garbaye J., Bouchard D., Churin J.-L., Argillier C., Amirault J.M., Généré B.,1997. Mycorhizes, pépinières et plantations forestières en France. Revue forestière française, vol. XLIX, n spécial "Champignons et mycorhizes en forêt, pp. 131-154.

[31] Nelson S.D., 1987. Rough and subsequent growth of woody ornamental softwood cuttings treated with endomycomhizal inoculum. J. Amer. Soc. Hort. Sci., 112 (2): $263-266$

[32] Nounsi A., Outcoumit A., Talbi Z., Touati J., Ait Aguil F., El Asri A., Ouazzani Touhami A., Benkirane R., Douira A., 2015. Effect of endomycorrhizal inoculation on the growth of Eucalyptus plants. Biolife, 3(3): 583-594.

[33] Nwaga D., Fankem H.,Obougou E., German E.O., Laurette N., Randrianangaly Jean S, 2007. Pseudomonas and symbiotic micro-organisms as biocontrol agents against fungal disease caused by Pythium aphanidermatum. African Journal of Biotechnology, 6 (3): 190-197,

[34] Ngonkeu M.E.L., Charles T., Amougou A., Dreyfus B., Chaintreuil C., Moulin L., Bena G., Nwaga D., Tondje P., 2007. Diversité moléculaire des mycorhizes à arbuscules des sols acides à toxicité aluminique et manganique de la zone forestière humides du Cameroun. Atelier du réseau de chercheurs sur les biotechnologies végétales, l'amélioration des plantes et sécurité alimentaire (BIOVEG),17-19 décembre 2007, Yaoundé, CRESA Forêt-Bois.

[35] Roldan-Fajero B.E. etBarea J.M., 1986. Mycorrhizal dependancy in the olive tree (Olea europaea L.). In. Physiological and genetical aspect of mycorrhizae, 323-326.

[36] Philips, J.M. \& Hayman, D.S.1970. Improved procedures for clearing root and staining parasitic and vesicular-arbuscular mycorrhizal fungi for rapid assessment of infection. Trans. Br. Mycol. Soc., 55: 158-161.

[37] Porras A., Soriano M.L., Poblador N., Porrassoriano M.L., 1999. Control inteligente de la propagación bajonebulización. Olivae 77 :53-55. 
[38] Porras A., Soriano M.L., Abenza J.M., Pérez De Los Reyes C., Aragón L.N., Porras-Soriano A., 2003. Micorrización de estaquillas de olivo propagadas bajo nebulización. Agricultura 856 : 784-787.

[39] Saad D., 2009. Etude des endomycorhizes de la variété Sigoise d'olivier (Olea europea L.) et essai de leur application à des boutures semi-ligneuses multipliées sous nébulisation. Mémoire Magister en biotechnologie, Univ. Oran, Algérie, 121p.

[40] Schellenbaum L., Berta G., Ravolanirina F., Tisserant B., Gianinazzi S., and Fitter A.H., 1991. Influence of Endomycorrhizal Infection on Root Morphology in a Micropropagated Woody Plant Species (Vitis vinifera L.). Annals of Botany., 68(2): 135-141.

[41] Sharma S., Parkash V., Aggarwal A., 2008. Glomales I: a monograph of Glomus spp. (Glomaceae) in the Sunflower rhizosphere of Haryana. India. Helia. Nr., 49: 13-18.

[42] Sidhoum W. and Fortas Z., 2013. Effect of Arbuscular mycorrhizal fungi on growth of semi woody olive cuttings of the variety "Sigoise" in Algeria. American Journal of Research Communication, 1 (11): 244-257.

[43] Smith D.E. \& Read D.J., 1997. Mycorrhizal Symbiosis. Academic Press, London.

[44] Stürmer S.L. and Morton J.B., 1999. Taxonomic reinterpretation of morphological characters in Acaulosporaceae based on developmental patterns. Mycologia, 91: 849-857.

[45] Talbi Z., El Asri A., Touati J., Chliyeh M., Ait Aguil F., Selmaoui K., Sghir F., Ouazzani Touhami A., Benkirane R. and Douira A., 2015. Morphological characterization and diversity of endomycorrhizae in the rhizosphere of Carob tree (Ceratonia siliqua) in Morocco. Biolife, 3(1): 196211.

[46] Tisserant B., Schellenbaum L., GianinazziPearson V., Gianinazzi S., Berta G., 1991.Infuence of infection by an endo-mycorrhizal fungus on root development and architecture in Plantanus acerifolia. Allionia, 30: 171-181.

[47] Trepanier M., 1998. Effets des champignons endomycorhiziens sur le bouturage et la croissance de plante ligneuses ornementales. Maîtrise ès sciences. Université Laval, Canada, 90p.

[48] Verkade S.D., Elson L.C., and Hamilton D.F. 1988. Effect of endomycorrhizal inoculation during propagation on growth following transplanting of Cornus serica cuttings and seedlings. Acta Hort. 27: 248-250.
[49] Vosatka M. 1995. Influence of inoculation with arbuscular mycorrizal fungi on the growth and mycorrhizal infection of transplanted onion. Agric. Ecosyst. Environ. 53: 151-159.

[50] Vosatka M., Jansa J., Regvar M., Sramek F., and Malcova R., 1999. Inoculation with mycorrhizal fungi-a feasible biotechnology for horticulture. Phyton 39: 219-224.

[51] Wilson D., Nayar N. K., and Sivaprasad P. 1997. Hardening and ex vitro establishment of rose plantlets. J. Trop. Agric. 37: 5-9. 